\title{
Bicycle Injuries in Children
}

\author{
A. W. CRAFT, D. A. SHAW, N. E. F. CARTLIDGE
}

British Medical fournal, 1973, 4, 146-147

\section{Summary}

An analysis of $\mathbf{4 0 5}$ bicycle accidents in children under 15 years of age resulting in their attendance at hospital has shown that those having accidents while riding modern "high-rise" bicycles suffered head injury and bone fracture and required hospital admission more frequently than did those riding conventional models. "High-rise" accidents tended to occur on newly acquired and borrowed machines, suggesting that lack of experience of the handling properties of these bicycles may be a factor in the causation of accidents.

\section{Introduction}

A recent survey of head injuries in children (Craft et al., 1972) included some due to bicycle accidents. It suggested that in these cases there may be a greater likelihood of injury when the child is riding a modern "high-rise" machine (a type with high handle-bars and a long seat with a back-rest) rather than a conventional bicycle. Of 200 children admitted to hospital with head injury 16 had had cycle accidents and, of these, 11 were riding high-rise machines. Anxiety had already been expressed about the stability and safety of these bicycles. Howell (1968) suggested that they tended to produce craniofacial injuries. A National Safety Council study (1970) reported that among cycle accidents a disproportionate number occurred on highrise as compared with conventional models. The Cornell Aeronautical Laboratory (Rice, 1970) carried out an evaluation of the performance of bicycles including high-rise styles and commented on several features in the latter that might predispose to reduced stability. On the other hand, Waller (1971), in a comparison of injuries in schoolchildren riding different types of bicycle, concluded that the high-rise models carried no increased risk of injury.

Following on from our original study and to explore further the possibility of a high-rise hazard, we have carried out a survey of bicycle accidents in children in the Newcastle region.

\section{Patients and Methods}

Details were recorded over a three-month summer period of 405 bicycle accidents occurring in children under 15 years of age and resulting in a visit to a hospital accident department. Eight departments in the Newcastle region participated and casualty officers were asked to complete a short questionnaire for every bicycle accident they saw. Items recorded were: age and sex of child, nature of injury, whether or not admitted to hospital, and type of bicycle ridden. To analyse the results the accidents were

Department of Neurology, Royal Victoria Infirmary, Newcastle upon Tyne

A. W. CRAFT, M.B., M.R.C.P., Research Registrar (Now Paediatric

Registrar)
D. A. SHAW, M.B., F.R.C.P., Senior Lecturer

N. E. F. CARTLIDGE, M.B., M.R.C.P., First Assistant divided into two groups according to whether the child had been riding a high-rise or conventional bicycle and the groups were compared in respect of each item recorded. To confirm the accuracy of the grouping and to obtain further information about the ownership of the bicycle and the experience of the rider a short questionnaire was sent to the parents of all the 114 children who had had high-rise accidents. Seventy replies were received, including three which indicated that the accident in fact belonged to the conventional group. In two cases the error had arisen because the bicycle in question was of a small-wheel variety but not a true high-rise type. In the third case the discrepancy was simply due to recording error. The groupings were appropriately adjusted in light of these replies but there was no confirmation of the casualty officer's record of the type of bicycle in the 44 accidents about which no reply was received.

\section{Results}

Of the 405 children included in the study 308 were boys and 97 were girls. The final grouping placed 294 children $(218$ boys and 76 girls) in the conventional and 111 (90 boys and 21 girls) in the high-rise category. The mean ages (table I) did not differ significantly between the groups.

TABLE I-Mean Ages and Standard Deviations in the Two Groups

\begin{tabular}{|c|c|c|c|c|c|}
\hline & & \multicolumn{4}{|c|}{ Type of Bicycle } \\
\hline & & \multicolumn{2}{|c|}{$\begin{array}{c}\text { Conventional } \\
(n=294) \\
\text { Boys } \quad \text { Girls }\end{array}$} & \multicolumn{2}{|c|}{$\begin{array}{l}\text { High-rise } \\
(\mathrm{n}=111)\end{array}$} \\
\hline $\begin{array}{l}\text { No. of children } \ldots \\
\text { Mean age (S.D.). }\end{array}$ & $\begin{array}{ll}\ldots & \ldots \\
\ldots & \cdots\end{array}$ & 218 & $\begin{array}{c}76 \\
8 \cdot 5(2 \cdot 8)\end{array}$ & $\begin{array}{c}90 \\
9 \cdot 2(2 \cdot 7)\end{array}$ & $\frac{21}{10 \cdot 2(2 \cdot 8)}$ \\
\hline
\end{tabular}

In many of the accidents there were multiple injuries (table II), particularly in the high-rise group, and hence the total number of injuries exceeds the total number of accidents. The incidence of abrasions, fractures, and head injuries is significantly higher in the high-rise than in the conventional group. Of the accidents involving riders of high-rise bicycles $25.2 \%$ resulted in hospital admission in contrast to $13.6 \%$ in the conventional group, the difference being significant $(P<0.01)$. On the basis of the questionnaire to parents we identified those highrise accidents which occurred to children on borrowed bicycles. There were 37 such accidents among the 67 on which details were available, and table III shows a comparison between the injuries sustained by those on borrowed bicycles and those riding their own. There is a significantly higher incidence of abrasions and head injuries among the children on borrowed bicycles. Furthermore, of the 30 children who had accidents while riding their own high-rise bicycle six had owned it for less than four weeks.

TABLE II-Types of Injury in Conventional and High-rise Bicycle Groups

\begin{tabular}{|c|c|c|c|c|c|c|}
\hline & & \multicolumn{2}{|c|}{ Conventional $(n=294)$} & \multicolumn{2}{|c|}{ High-rise $(n=111)$} & \multirow{2}{*}{$\begin{array}{c}\text { Significance } \\
\text { of Difference } \\
\left.\text { ( } \chi^{2} \text { test }\right)\end{array}$} \\
\hline & & No. & $\%$ & No. & $\%$ & \\
\hline $\begin{array}{l}\text { Abrasion } \\
\text { Laceration } \\
\text { Fracture .. } \\
\text { Head injury } \\
\text { Other ... }\end{array}$ & $\begin{array}{l}\ldots \\
\ldots \\
\ldots \\
\ldots\end{array}$ & $\begin{array}{r}124 \\
91 \\
55 \\
55 \\
63\end{array}$ & $\begin{array}{l}42 \cdot 2 \\
31 \cdot 0 \\
18 \cdot 7 \\
18 \cdot 7 \\
21 \cdot 4\end{array}$ & $\begin{array}{l}64 \\
37 \\
35 \\
39 \\
24\end{array}$ & $\begin{array}{l}57.7 \\
33.3 \\
31.5 \\
35.1 \\
21.6\end{array}$ & $\begin{array}{l}\mathrm{P}<0.01 \\
\text { N.S. } \\
\mathrm{P}<0.01 \\
\mathrm{P}<0.001 \\
\text { N.S. }\end{array}$ \\
\hline
\end{tabular}

N.S. = Not significant. 


\begin{tabular}{|c|c|c|c|c|c|c|}
\hline & & \multicolumn{2}{|c|}{ Own $(n=30)$} & \multicolumn{2}{|c|}{ Borrowed $(n=37)$} & \multirow{2}{*}{$\begin{array}{l}\text { Significance } \\
\text { of Difference } \\
\left.\text { ( } \chi^{2} \text { test }\right)\end{array}$} \\
\hline & & No. & $\%$ & No. & $\%$ & \\
\hline $\begin{array}{l}\text { Abrasion } \\
\text { Laceration } \\
\text { Fracture .. } \\
\text { Head injury } \\
\text { Other } \\
\text { Admitted }\end{array}$ & $\begin{array}{l}\ldots \\
\ldots \\
\ldots \\
\ldots\end{array}$ & $\begin{array}{r}12 \\
11 \\
11 \\
5 \\
6 \\
6\end{array}$ & $\begin{array}{l}40 \cdot 0 \\
36 \cdot 7 \\
36 \cdot 7 \\
16 \cdot 7 \\
20 \cdot 0 \\
20 \cdot 0\end{array}$ & $\begin{array}{r}27 \\
9 \\
9 \\
18 \\
7 \\
10\end{array}$ & $\begin{array}{l}73 \cdot 0 \\
24 \cdot 3 \\
24 \cdot 3 \\
48 \cdot 6 \\
18 \cdot 9 \\
27 \cdot 0\end{array}$ & $\begin{array}{l}\text { P }<0.01 \\
\text { N.S. } \\
\text { N.S. } \\
\text { P }<0.01 \\
\text { N.S. } \\
\text { N.S. }\end{array}$ \\
\hline
\end{tabular}

\section{Discussion}

The results show that in this group of children injured in bicycle accidents there was a higher incidence of abrasions, fractures, and head injuries among those riding high-rise models compared with those on conventional machines. Furthermore, admission to hospital as a result of injury was commoner after high-rise cycle accidents. There is a variety of possible explanations for these differences but attention is drawn to the fact that surprisingly many high-rise accidents occurred when on borrowed machines and in these the injuries tended to be more severe (table III). Also, a fifth of the children injured while riding their own high-rise bicycle had recently acquired it, and this figure was even higher in our earlier study, which covered the Christmas period. These facts suggest that unfamiliarity with the high-rise type of cycle may be respon- sible for many of the accidents which appear to cause more severe injury to inexperienced riders.

Many activities in childhood carry some risks of injury and the results of this study must be seen in perspective. All bicycles are potentially dangerous and the figures presented here are not necessarily a condemnation of the high-rise type. So far as this study goes the style has shown itself to carry some extra hazard and parents should clearly be informed of the safety factor whether relating to toys, bicycles, or other articles which they buy for their children. One important point to emerge is that unfamiliarity with the machine is a factor in high-rise accidents.

We are greatly indebted to the Newcastle Regional Hospital Board for its support of our studies in head injury, including the provision of a research registrarship for A.W.C. We thank all the casualty officers and heads of accident departments for their willing cooperation, and we are grateful to Dr. Hugh Jackson for his interest in this study. Finally, we are indebted to Mrs. D. Weightman for statistical help.

\section{References}

Craft, A. W., Shaw, D. A., and Cartlidge, N. E. F. (1972). British Medical fournal, 4, 200

Howell, T. R. (1968). Pediatrics, 42, 214.

National Safety Council (1970). National Commission on Product Safety. Final Report. Washington D.C., Government Printing Office.

Rice, R. S. (1970). Technical Report No. CAL. VJ-2888-K. Buffalo, New York, Cornell Aeronautical Laboratory.

Waller, J. A. (1971). Pediatrics, 47, 1042

\section{MEDICAL MEMORANDA}

\section{Pyrimethamine Poisoning}

\author{
OLU AKINYANJU, J. C. GODDELL, I. AHMED
}

British Medical fournal, 1973, 4, 147-148

Pyrimethamine (Daraprim) is an amyl analogue of 2,4-diaminopyrimidine which binds dihydrofolate reductase and acts as a folate antagonist, thus preventing nuclear division (Hamilton et al., 1952). It has been used for the treatment of malaria

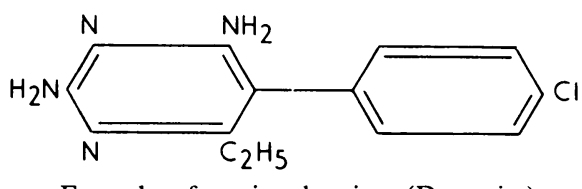

Formula of pyrimethamine (Daraprim).

(Covell, 1953), toxoplasmosis (Grisham, 1962), and polycythaemia vera (Isaacs, 1954). Its efficacy when administered in a once-weekly dose of $25 \mathrm{mg}$ for adults and its tastelessness and relative freedom from toxic allergic reactions, have commended it for wide use as a malarial prophylaxis drug in Nigeria. It is not commonly regarded as a dangerous drug, and is publicly

Lagos University Teaching Hospital, Lagos, Nigeria

OLU AKINYANJU, M.B., M.R.C.P., Consultant in Clinical Haematology

J. C. GODDELL, F.R.C.P. (CAN.), Consultant in Paediatrics

I. AHMED, M.R.C.P., F.M.C.PAED.(NIG.), Consultant in Paediatrics advertised and easily obtained without a prescription. In spite of its widespread use we are not aware of reports of its toxicity from Nigeria. We report two cases of successfully treated pyrimethamine poisoning and discuss the treatment.

\section{Case 1}

A 14-month-old male Caucasian child weighing $10.4 \mathrm{~kg}$ was admitted to this hospital about two hours after ingesting $450 \mathrm{mg}$ of pyrimethamine tablets. Half an hour after ingestion his parents observed an unsteady gait and a vacant expression on his face. During the next half hour he vomited several times, lost consciousness, and began to convulse every few minutes.

On examination he was unconscious, cyanosed, and had almost continuous generalized convulsions and a hyperpyrexia of $40.6^{\circ} \mathrm{C}$. He had a tachycardia of $146 / \mathrm{min}$, tachypnoea, and dyspnoea, with bilateral rales heard over both lower lung fields.

Oxygen was administered, and the convulsions were controlled by giving intravenous diazepam $5 \mathrm{mg}$.

Intramuscular liver extract $2 \mathrm{ml}$ and folic acid $10 \mathrm{mg}$ were also given. An intravenous drip containing $100 \mathrm{ml}$ of $10 \%$ mannitol was given within 30 minutes and then $4 \cdot 3 \%$ dextrose and $0 \cdot 18 \%$ saline were continued at the rate of 1.21 . a day. Sodium bicarbonate and potassium chloride were added to correct acidosis and electrolyte imbalance. The child was put on broad spectrum antibiotics, intramuscular diazepam $3 \mathrm{mg}$ eight-hourly, folic acid, and liver extract.

Investigations on admission were: packed cell volume (P.C.V.) $35 \%$; W.B.C. $10,500 / \mathrm{mm}^{3}$; blood urea $44 \mathrm{mg} / 100 \mathrm{ml}$; sodium 125 $\mathrm{mEq} / 1$; potassium $3.2 \mathrm{mEq} / \mathrm{l}$; chloride $100 \mathrm{mEq} / \mathrm{l}$; bicarbonate $8 \mathrm{mEq} / 1$; ; bilirubin $0.6 \mathrm{mg} / 100 \mathrm{ml}$; alkaline phosphatase 28 units; SGOT 122 units; and SGPT 32 units. Cerebrospinal fluid was normal. An $x$-ray picture of the chest showed patchy opacities at both lung bases, and $x$-ray appearances of the skull were normal.

During the next 24 hours the child's condition continued to cause anxiety. The respiration remained hurried and laboured with bilateral rales; fever ranged from $40-40 \cdot 6^{\circ} \mathrm{C}$, and he remained unconscious and 